\title{
RISK AND RADIATION EXPOSURE IN ORTHOPEDIC SURGERY OF THE SPINE IN MEXICO
}

\author{
RISCO E EXPOSIÇÃO À RADIAÇÃO EM CIRURGIA ORTOPÉDICA DA COLUNA NO MÉXICO \\ RIESGO Y EXPOSICIÓN A RADIACIONES EN CIRUGÍA ORTOPÉDICA DE COLUMNA \\ VERTEBRAL EN MÉXICO
}

Fernando Ivan Zaragoza Noriega ${ }^{1}$, Fernando Hiramuro Hirotan ${ }^{1}$

\begin{abstract}
Objective: To find a biological effect by means of detection of the thyroid profile in research personnel, and a physical effect through radiation detection plates type Durr. Methods: Five medical residents (four of first year and one of second) were submitted to the study of the basal thyroid profile, and annually after a year of radiation exposure. In two of them five plates of Durr type were placed by surgery at different body parts and 20 separate surgeries, using fluoroscopy, a total of 200 plates exposed. Results: Three residents had decreased thyroid-stimulating hormone and two had a significant increase. Ninety-one plates were exposed, most of which corresponds to the neck (thyroid). Conclusion: Biological and physical changes were observed that require us to realize and implement protective measures against radiation, at least in the neck, because the thyroid is susceptible to radiation.
\end{abstract}

Keywords: Fluoroscopy; Radiation; Risk factors; Orthopedics; Humans.

\section{RESUMO}

Objetivo: Encontrar um efeito biológico através da detecção do perfil da tireoide dos profissionais de investigação, e um efeito físico através da detecção de radiação com placas tipo Durr. Métodos: Cinco médicos residentes (quatro de primeiro ano e um de segundo) foram submetidos ao estudo do perfil tireoidiano basal, e anualmente após um ano de exposição à radiação. Em dois deles, foram colocadas cinco placas de Durr por cirurgia, em diferentes partes do corpo e em 20 cirurgias distintas, utilizando-se fluoroscopia, perfazendo um total de 200 placas expostas. Resultados: Três residentes tiveram diminuição do hormônio estimulador da tireoide e dois, um aumento significativo. Foram expostas 91 placas, cuja maioria corresponde ao pescoço (tireoide). Conclusão: Foram verificadas mudanças biológicas e físicas que nos impulsionam à conscientização e implementação de medidas de proteção contra a radiação, pelo menos no pescoço, uma vez que a tireoide é suscetível à radiação.

Descritores: Fluoroscopia; Radiação; Fatores de riscos; Ortopedia; Humanos.

\section{RESUMEN}

Objetivo: Encontrar un efecto biológico mediante detección de perfil tiroideo al personal investigador, y un efecto físico mediante detección de radiación con placas tipo Durr. Métodos: Fueron sometidos al estudio, cinco médicos residentes, (cuatro de primer año y uno de segundo) para el perfil tiroideo basal, y anual después de un año de radiación. A dos de ellos les fueron colocadas cinco placas de Durr por cirugía, distribuidas en diferentes partes del cuerpo en 20 cirugías distintas con la utilización de fluoroscopio, dando un total de 200 placas expuestas. Resultados: En tres de los residentes hubo una disminución de la hormona tiroidea estimulante y en dos un aumento significativo. Se expusieron 91 placas siendo la mayoría de estas correspondientes al cuello (tiroides). Conclusión: Se encontraron cambios biológicos y físicos que nos impelen a tomar conciencia y medidas necesarias de radioprotección por lo menos a nivel del cuello, ya que la tiroides es susceptible a las radiaciones

Descriptores: Fluoroscopía; Radiación; Factores de riesgo; Ortopedia; Humanos.

\section{INTRODUCTION}

Over a one year period, 2600 orthopedic surgeries were conducted in the Orthopedics department of Hospital Civil Fray Antonio Alcalde en Guadalajara. Of this total, 1100 were surgeries involving the spine, with the aid of a " $\mathrm{C}$ " arm. The use of this device is therefore increasing, leading to an increased risk of exposure to radiation among medical staff. These past few years, the use of fluoroscopy in orthopedic surgery has been increasing due to the frequency of surgeries such as placement of transpedicular vertebral nails, vertebroplasty surgery, spine fractures in children, open corrections of scoliosis, targeted vertebral tumor biopsies, and others; therefore, the level of radiation is higher for both the patient and the medical staff.

In addition to the prolonged exposure times for the patient, these surgeries are more extensive, resulting in increased exposure for the medical staff involved in the surgery.

The C-arm fluoroscope is an appliance that consists of an issuer that emits radiation, which hits a receiver, where it is translated into a sharp, dynamic image.

Exposure and doses of radiation also depend on the quality and make of the fluoroscope, the quantity of rays emitted by the issuer, and the distance between the medical professional and the receiver.

This can be checked by the inverse square law and the distribution law of backscatter. ${ }^{1.2}$

The fluoroscope must have a pedal, which is controlled by the primary surgeon and prevents inaccurate triggers due to the accommodation of the $\mathrm{C}$ arm.

The current universal unit, both in the United States and Mexico,

1. Hospital Civil “Fray Antonio Alcalde". Guadalajara, Jalisco, Mexico. 
is the REM (Roetgen Equivalent Man), reflects the biological response to ionizing radiation in man.

There are various amendments for protecting medical personnel from radiation, as recommended by the official Mexican regulations, and for the annual permitted dose, which is between 2 and 5 REM. ${ }^{2.3}$

The biological effects of radiation therapy may be at the molecular, cellular, or histological levels, depending on the dose of radiation. It should also be borne in mind that the $\mathrm{C}$ arm emits secondary radiation, in which the dose is negligible. -10 $^{-10}$

Three main methods used to measure radiation are:

1. Customized dosimeters,

2. Thermoluminescent dosimeters,

3. Durr type plates, which are only used to detected radiation, not to measure its quantity. (Figure 1)

The purpose of this study was to determine the biological and physical effects of radiation on our resident doctors in their first year at our institution, by detecting the radiation levels in different radiosensitive different parts of the body, such as the thyroid, chest, hands and gonads; with the aim of increasing awareness of the importance of knowing how to protect oneself adequately against radiation, decreasing the risk to which we are exposed.

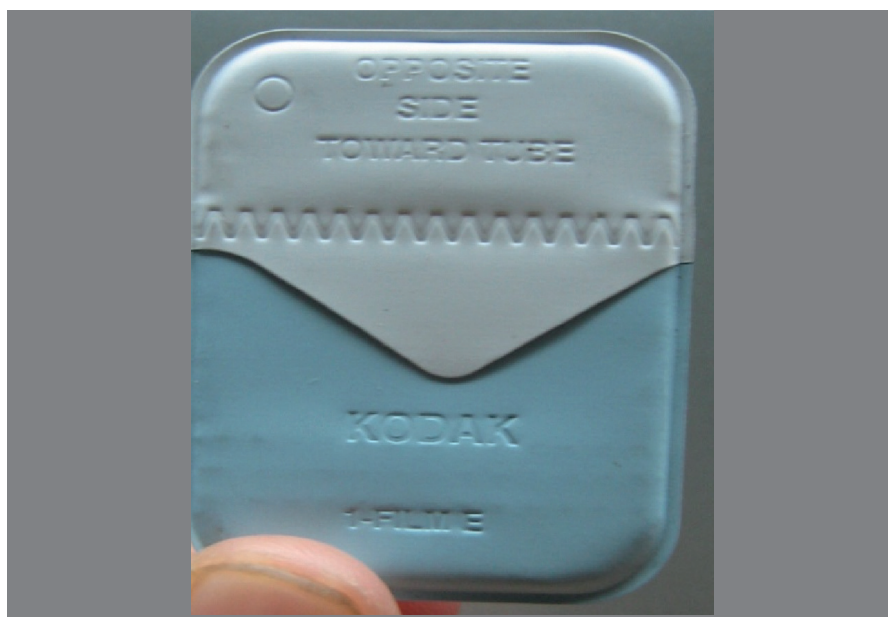

Figure 1. Durr type plate

\section{MATERIAL AND METHODS}

A prospective experimental study was conducted from March 2009 to March 2010, in the blood laboratory to determine the biological effects, and in the operating theaters of Hospital Civil "Fray Antonio Alcalde" to determine the physical effects. This experiment was approved by the Honor, Justice and Ethics Committee of the hospital.

The study to determine the biological effects consisted of a baseline blood sample of 4 first year residents of the orthopedics services, numbered 1 to 4 , and one second year resident (principal investigator), numbered 5 , who were the protagonists of this study $(\mathrm{N}=5)$.

To determine the thyroid profile, another sample was taken after one year exposure to fluoroscopy surgeries without neck protection. Both profiles were compared, to determine whether there was a significant difference. First year residents were submitted to the study for the reason that they had not received ionizing radiation in the year prior to admission, and second year residents were included due to their experience of surgeries, and particularly, to determine the physical effects.

To determine the physical effects, 2 volunteers were submitted to the study, a surgeon and an assistant, both having signed an informed consent form. The surgeon was a second year resident, while the assistant was first year resident number 1.
They performed a total of 20 fluoroscopy surgeries: 5 vertebroplasties, 5 lumbar spine instrumentations at different levels, 5 discoidectomies and lamintectomies, 5 biopsies, and infiltrations of the lumbar and thoracic spine, using, in each case, a Philips 2004 C-arm.

The study consisted of placing Durr plates over the different parts of the body most frequently exposed to radiation; 5 for the surgeon and 5 for the assistant, making a total of 10 plates exposed to radiation by the surgery - 100 plates for each subject across the 20 surgeries, resulting in a total of 200 Durr plates used for the study.

The plates were distributed as follows: 1 for the neck, over the thyroid glands, 1 for the chest, 1 for the gonads, over the groin, and 1 for each of the hands. The plates were adhered to the body using Durapore surgical tape.(Figure 2)

The plates for the hands were attached using a sterile technique and double glove; this could increase the risk of infection for the patient, therefore only patients with a previously who had signed an informed consent for prior to the surgery, informing them of this risk, were submitted to the procedure. (Figures 3 and 4)

There was no protection for the radiation.

The surgeon always stood at a distance of less than $30 \mathrm{~cm}$ from the receiver of $\mathrm{C}$ arm, and always on the side of the arm.

The assistant always stood on the opposite side of the arm, so as to apply the backscatter and inverse square laws.

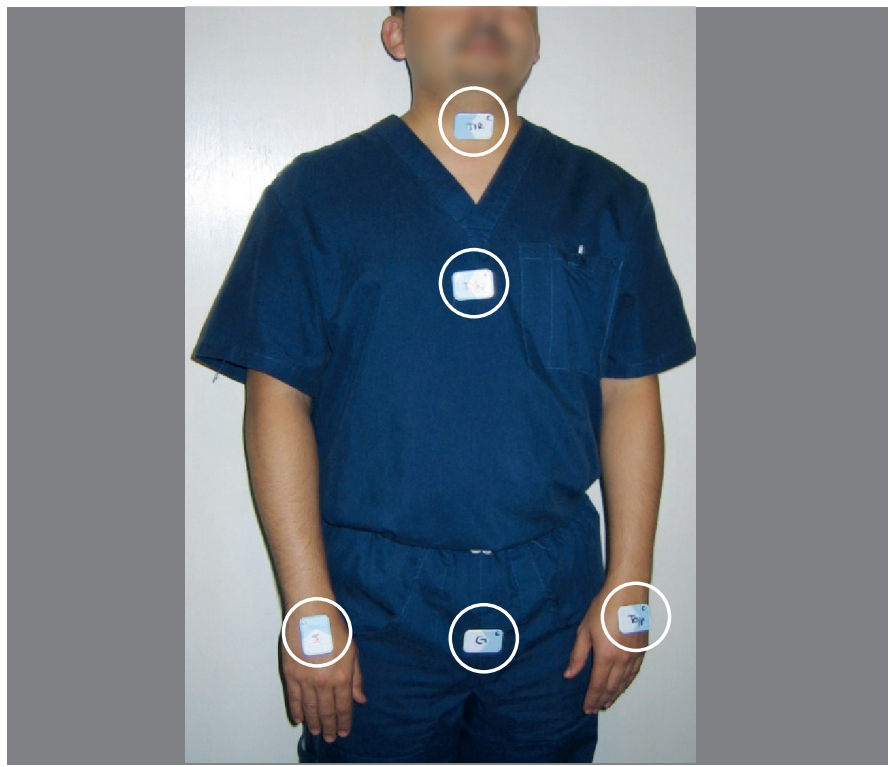

Figure 2. Distribution of the plates

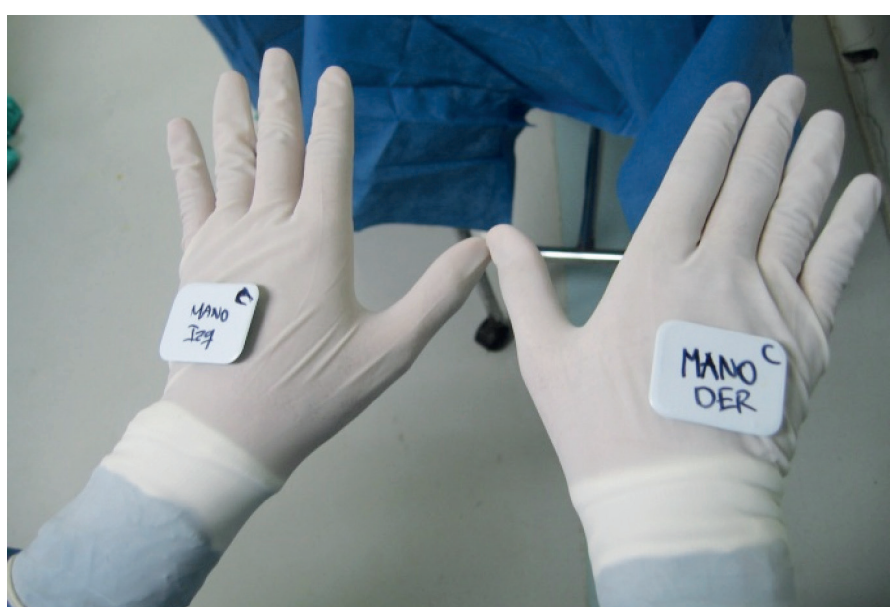

Figure 3. Placement of the plates on the surgeon's hands. 


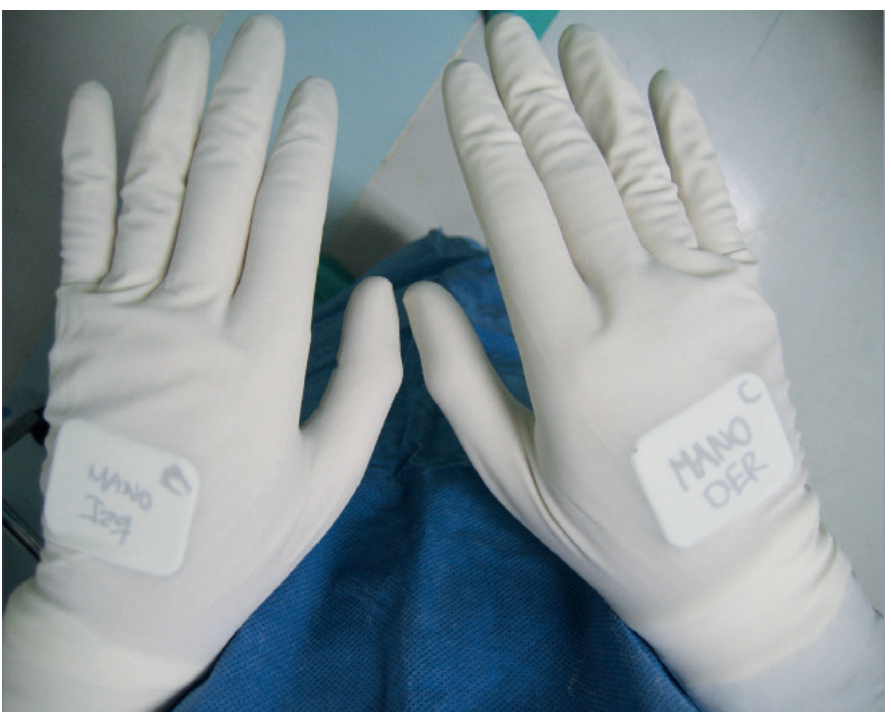

Figure 4. Sterile gloves worn over the plate.

\section{RESULTS}

The thyroid profiles of the subjects exposed to the radiation were compared. It was found that there was an increase in thyroid stimulating hormone (TSH) in 2 subjects, and a decrease in the remaining 3.

The average increase in TSH was 0.9UI, and the decrease was 2.43UI. T4 decreased in all 5 subjects, resident number 1 had a more marked increase in TSH than the other residents, and number 5 had a significant decrease. (Figure 5)

Of the 200 plates potentially subjected to radiation, 91 of them had been exposed to it. Of these, 57 were taken from the surgeon and 34 from the assistant. The distribution was a total of 39 positive plates for the neck, 22 from the chest, 16 from the gonads, 7 from the dominant hand and 9 from the non-dominant hand. (Figure 6)

The average radiation for the 20 surgeries was approximately $1 \mathrm{~min}$, $50 \mathrm{sec}$., while the average for all 1100 surgeries was 1 min, $30 \mathrm{sec}$.

The plates placed on both surgeons' necks were positive for radiation in almost all cases, (39 out of 40 ); 20 were positive for the surgeon and 19 for the assistant.

By contrast, for the other regions of the body, there was a significant difference in radiation levels, which were higher for the surgeon than for the assistant. (Figure 7)

The plates were developed manually, in groups of 10 , in the X-ray department of the same hospital.

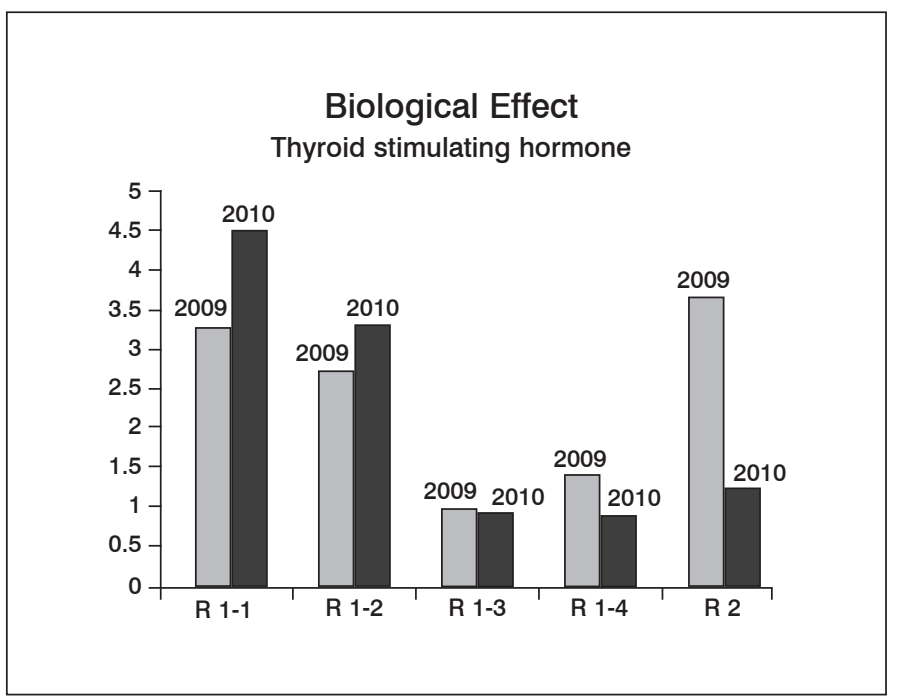

Figure 5. Thyroid profile - baseline and annual.

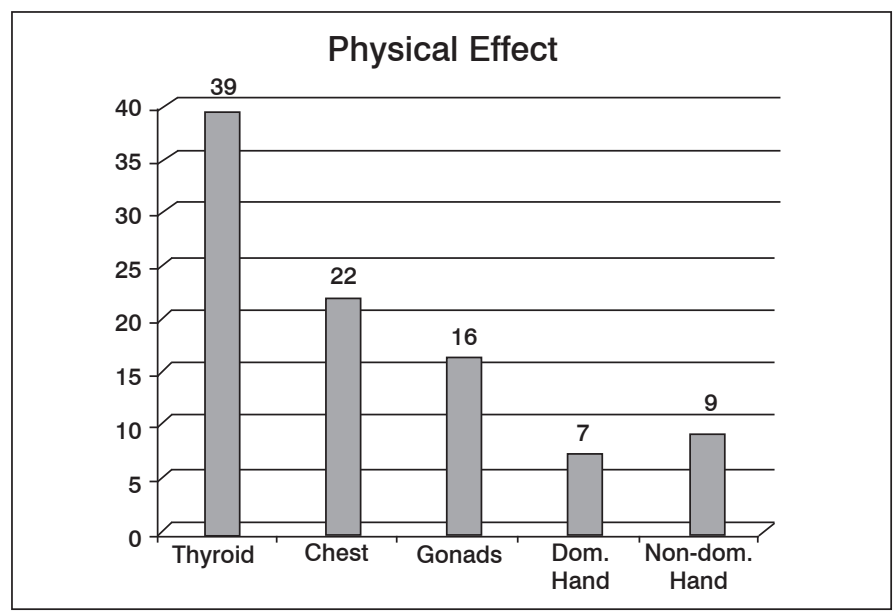

Figure 6. Total number of plates exposed.

\section{Exposed plates}

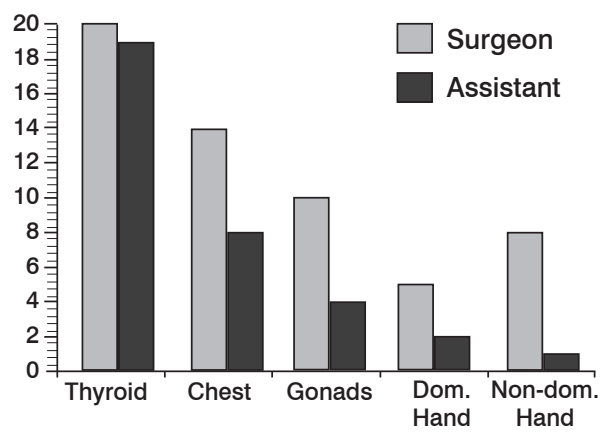

Figure 7. Exposed plates taken from the surgeon and the assistant.

\section{DISCUSSION}

The assistant had less plates exposed to radiation, due to the greater distance from the $\mathrm{C}$ arm, thereby verifying the Backscatter dispersion and inverse square laws, as the operator on the same side received more radiation. (Figures 8 and 9)

Another important factor is the radiation time during a surgical procedure. For the purposes of comparison, 280 intramedullary nailing procedures were conducted at this hospital over the one-year period, with an average radiation time of $1 \mathrm{~min} 11 \mathrm{sec}$, compared

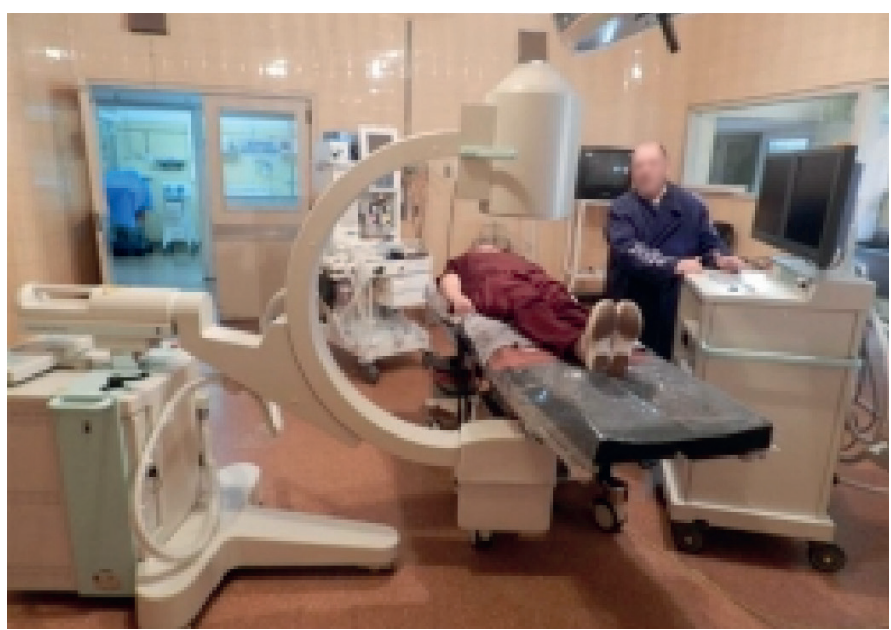

Figure 8. Inverse square law and distribution law of backscatter. 


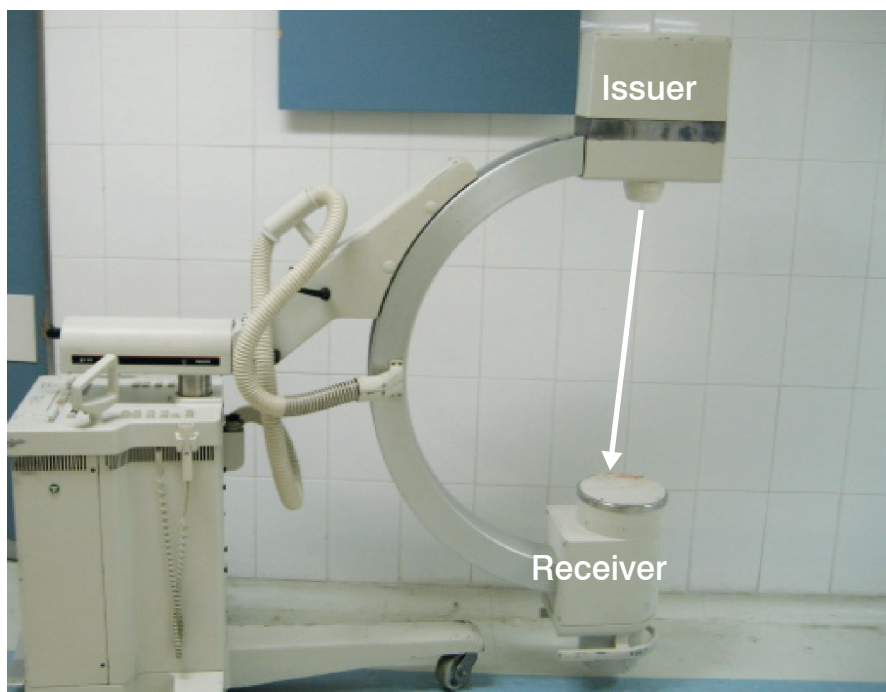

Figure 9. The light beam is sent from the issuer to the receiver, where it is translated into a sharp, dynamic image. with 119 in the Hospital of Denver, with an average radiation time of 2 min 18 sec. However, the US Hospital had all the necessary radioprotection, from protective lenses to lead collar, collar, apron, gloves, as well as surgical gowns containing bismuth oxide antiradiation material for the patient, all of which decreases the risk of radiation by $85 \%$.

\section{CONCLUSIONS}

We found biological and physical changes that compel us to raise awareness and take the necessary protective measures, at least for the neck area, as the thyroid is susceptible to radiation. However, we must always quantify the radiation time in each surgery, with the surgeon using a pedal, standing as far away as possible from the issuer, and avoiding placing the hands in the beam of light.

Fluoroscopy is increasingly becoming an indispensable routine in orthopedic surgery.

It is a reality, and we must be prepared.

All authors declare no potential conflict of interest concerning this article.

\section{REFERENCES}

1. Theocharopoulos N, Damilakis J, Perisinakis K, Papadokostakis G, Hadjipavlou A, Gourtsoyiannis N. Image-guided reconstruction of femoral fractures: is the staff progeny safe? Clin Orthop Relat Res. 2005;(430):182-8.

2. Singer G. Occupational radiation exposure to the surgeon. J Am Acad Orthop Surg. 2005;13(1):69-76

3. Bushberg JT, Seibert JA, Leidholdt EM Jr, Boone JM, editors. The Essential Physics of Medical Imaging. Philadelphia: Lippincott Williams \& Wilkins; 2004.

4. Norris TG. Radiation safety in fluoroscopy. Radiol Technol. 2002;73(6):511-33.

5. Badman BL, Rill L, Butkovich B, Arreola M, Griend RA. Radiation exposure with use of the mini-C-arm for routine orthopaedic imaging procedures. J Bone Joint Surg Am. 2005;87(1):13-7.
6. Delgado GJL. Norma Oficial Mexicana. Requerimientos para la calificación y entrenamiento del personal ocupacionalmente expuesto a radiaciones lonizantes. NOM. 2007;31(4):1-5.

7. Tremains MR, Georgiadis GM, Dennis MJ. Radiation exposure with use of the invertedc-arm technique in upper-extremity surgery. J Bone Joint Surg Am. 2001;83-A(5):674-8.

8. Theocharopoulos N, Perisinakis K, Damilakis J, Papadokostakis G, Hadjipavlou A, Gourtsoyiannis $\mathrm{N}$. Occupational exposure from common fluoroscopic projections used in orthopaedic surgery. J Bone Joint Surg Am. 2003;85(9):1698-703.

9. Ortega $A X$, Bisbal J. Radiaciones lonizantes: utilización y riesgos II. España: Editorial Barcelona UPC; 2006.

10. Alonso JA, Shaw DL, Maxwell A, McGill GP, Hart GC. Scattered radiation during fixation of hip fractures. Is distance alone enough protection? J Bone Joint Surg Br. 2001;83(6):815-8. 